\title{
Purchase intention on Indonesia male's skin care by social media marketing effect towards brand image and brand trust
}

\author{
Lim Sanny ${ }^{a^{*}, \text { Aisha Nur Arina }}{ }^{a}$, Ratu Tasha Maulidya ${ }^{a}$ and Ressy Putri Pertiwi ${ }^{a}$
}

${ }^{a}$ Management Program, Management Department, BINUS Business School Master Program, Bina Nusantara University, Jakarta, Indonesia

\section{CH R O N I C L E}

\section{Article history:}

Received: February 15, 2020

Received in revised format:

March 162020

Accepted: March 16, 2020

Available online:

March 16, 2020

Keywords:

Brand Image

Brand Trust

Male's Skincare

Purchase Intention

Social Media Marketing

\section{A B S T R A C T}

This paper investigates the impact of social media marketing on brand image and brand trust toward the purchase intention of Indonesian Male's Skincare. The study proposes a model that shows the effect of skincare marketing strategies through social media for male millennials generations. A quantitative approach is used to collect the data to support the model using online surveys. The data samples are collected from 203 male respondents using non-probability sampling techniques with convenience sampling method. The results are analysed with PLS-SEM methodologies by SmartPLS, considered to be applied when the research is exploratory. The research result shows that social media marketing had a significant impact on brand image and brand trust. Moreover, brand trust and brand image had significant impacts on purchase intention. With brand image and brand trust 56.1 percent explained the purchase intention, 53.6 percent social media marketing explained the brand image, and 65.4 percent of the social media marketing explained the brand trust as well.

O 2020 by the authors; licensee Growing Science, Canada

\section{Introduction}

These days markets competition has become much more intense, to differentiate similar products branding is an important competitiveness factor for a business to shape perspective in consumers' mind and make the products more attractive. The firms that can set consumers' minds had an exclusive position in consumers' mind and successfully identify their business' characteristics. Therefore, Seo and Park (2018) revealed that brand image would form a physical structure in the consumers' mind and it would be able to become a key marketing element. Furthermore, after the brand image is stated in the consumers' minds, they will have certain expectations of the product itself. When these products are able to meet their expectations, trust of the brand is built (Takaya, 2019). Razy and Lajevardi (2015) conclude that a way to reduce purchase risks for consumers is to prefer to purchase familiar brand products with the positive brand image. This is where the brand image leads an important role in affecting the purchase intention in a decision-making process (Foster, 2016). Moreover, consumers' need to get brand trust comes as the lead in their purchasing intentions, especially at confusion to choose among similar products and risks seen as immense. Under these conditions trust will direct characteristic that provides as a shortcut on a purchasing intention (Aydin, 2014). These business characteristics are precisely related to the communication between the brand and the consumer. Hence, businesses are bringing out studies to engage consumers' perspective to the brand, to be set it up in their minds, shaping a positive brand image and to strengthen brand trust by engaging with all the communication channels in order to shape the brand (Bilgin, 2018). Cosmetic industries are considered only associated with colours or make up, in fact it has five broad categories (skin care, hair care, makeup, fragrance, and personal hygiene). The largest part of the cosmetics industry is associated with skin care products which at 37 percent, with the United States considered the most valuable beauty and personalcare market in the world, says market research firm Statista. Women — and a growing number of men — estimated to spend

* Corresponding author. Tel: +62 85710571409

E-mail address: Lsanny@binus.edu (L. Sanny) 
from $\$ 6.4$ billion in 2012 to $\$ 7$ billion in 2017 on anti-aging products (Yee, 2018). Approximately US\$120bn from skin care's market size is dominating the total global value of 2 overall beauty industries in 2016 amounted to $\$ 444 \mathrm{bn}$. Further market research reported that the global skincare market is expected to reach $\$ 179$ billion by 2022 with a CAGR of 4.7 per cent from 2016 to 2022 (Lee et al., 2019). Among thousands of variants of skincare available in the market, millennials are considered more selective, personalized and customized in their product preference. Since millennials have grown up with a great number of choices, they look further for a variety of products and the thought that such a lot of choices is their birth-righter. That made millennials less traditional in their consumer choices from the other generations. They wish to be able to fully lead over what they want, how to get and when they want it (Junaid \& Nasreen, 2012).

In this Era, to discover and choose beauty products about sixty-five percent of teens rely on social media. Social media has become one of the common channels that firms have recently used for their marketing activities in terms of communications. Thus, as the largest country in Southeast Asia, Indonesia has active social media users for about 150 million (56\%) out of total populations which dominated by 18-34 ages of social media's users (Kemp, 2019). The use of social media in a business is to be believed as one of the attractive marketing tools, they will able to conduct two- way communication, reviews, offering campaigns and other relevant content to attach, interact, make them involved, strengthen the relationships and create value for customers (Tatar \& Erdoğmuş, 2016). The social media delivers 87\% as purchase Intention on Indonesia Male's Skin Care by Social Media Effect Towards Brand Image and Brand Trust a middle touch point on the path to purchase, making it more expected than the other marketing channel (MDG Advertising, 2014).

Cosmetic products have been mostly related to women for years, since the cosmetic industry has offered the product in terms of beauty and feminine. But nowadays the situation has changed, men are more aware and concerned about their self-appearance since younger age to older age of the importance of beautifulness, boyish charm, and fitness which separate market for male consumers. Youthful and charming looks are attached in their mindsets that would enable them to reinforce their confidence and reputation in the workplace, during client meetings, social dating and in their daily lives. Based on statistics, 64.4 percent of men take extreme care of their skin condition (Eng et al., 2018). This situation gives manufacturers of this skincare industry a big opportunity since male consumers in the cosmetic market is highly increasing. The percentage in western countries is high, and it is growing rapidly in developing countries (Khan et al., 2017). Both for men and women, having flawless and bright skin is seen as a particularly important stamp of beauty in Indonesia, as in 3 other Asian countries since the fair-skin beauty are often shown in TV shows and on magazine covers and strengthened through social media among the country's young and internet-savvy population. Male consumer aspect increasingly on the radar of cosmetic firms worldwide, and in Indonesia this segment of the market is just starting point to take off.

Indonesian men are a fresh market segment for the cosmetic industry. Based on cosmetics companies, they reported sales growth for male product lines are multiple of the growth rates on female products. And male's skin care products will remain to increase along with the awareness' growth for the importance of skincare treatment for males. Nielsen's data shows $13.5 \%$ of the growing number of men which are more concerned about their skin care in Indonesia from 2010 to 2011 , with face cleanser, anti-aging and skin whitening products as the highest growing market (Herdiyanti \& Titus, 2013). These products are becoming popular among Indonesian men, such as facial cleansers and moisturizers by the advertising campaigns are shown male celebrities and starring bikers seek to dispel the notion that using them is effeminate (Global Business Guide, 2014). Grooming products are attracting the attention of men's shopping behaviours and considerations as men's priority to purchase. Previous research (Herdiyanti \& Titus, 2013) has only shown trends on male's skin care products in Indonesia along with the mostly skin concerns, that is likely more descriptive rather than knowing what made them intend to buy the male's skincare product. The other research by Hermanda et al. (2019) has only discovered women purchase intention on cosmetic products in Indonesia through social media influencer. Based on the research background and previous research in Indonesia, where the research only examined the development of male skincare and women's purchase intention on skincare make the research of this subject is still limited in Indonesia in terms of its constructs. The purpose of this research is to conduct furtherly comprehend, the concept of purchase intention on Indonesia's skincare by social media marketing effect towards the brand image and brand trust and formulate the implemented managerial implications on giving insight for the skincare industry to start concern on developing skincare products for male.

\section{Literature review and hypotheses}

Social media can be described as an online application program, platform, or mass media tool that is able to facilitate communication, collaboration, or sharing information among users in general and direct sales, customer gain, and customer retaining for a business (Bilgin, 2018). Social media marketing is one of the marketing strategies used by successful businesses in order to be part of the online consumers network (Elaydi, 2018). In addition, Karman (2017) revealed that digital word of mouth drives social media marketing into the fast-growing marketing phenomenon. Godey et al. (2016) described social media marketing consist of five dimensions: entertainment, interaction, trendiness, customization, and word of mouth (WOM). While Bilgin (2018) considered social media marketing activities as entertainment, interaction, trendiness, advertisement and customization. In this research, social media marketing will be categorized as entertainment, advertisement, interaction, trendiness, customization, and word of mouth (WOM). Brand image is customer's perceptions about a brand promoted by the interaction of the affective, cognitive, and evaluative processes in a customer's mind (Lee et al., 2019). The Brand image is 
an overall representation of product's information and knowledge that leads to perception of the brand itself (Wijaya \& Wijaya, 2013). Brand image is also associated with belief and perception held by the consumer about a brand (Foster, 2016). Consumers perceive toward products based on brand image where the higher brand image has better quality and value (Sallam, 2016). The consumer's perception of a product brand image is so powerful that might their intention to shop a product with a high brand image. Brand trust is seen as central in many studies (Kabadayi \& Alan, 2012). Trust is defined as a customer believes that certain brands can satisfy her or his desires, so when customers have trust in the brand, repetitive buying behaviour will be created, which leads to commitment to the brand, and the relationship between the brand and the customer can be established (Chinomona,2017). According to Cakmak (2016), brand trust has the ability, capability, capacity needed to obtain the desires, and needs of consumers, described as the intention of consumers towards the brand, considering the benefits of consumers, and solutions to problems. Chaudhuri and Holbrook (2001) believe that brand trust involves a process that is carefully thought out and carefully considered. Kim et al. (2019) describe brand trust as an essential factor in specifying an individual's attitude in a business relationship. Thus, managers have to perceive it as a key to success in business transactions. Purchase intention is an activity where consumers consider purchasing a product or a service. Set of consumers' behaviour, attitude and perception also related to consumer's purchase intention (Hermanda et al., 2019). From journals, researchers stated many factors affecting purchase intentions include brand image (Foster, 2016). Rahmaningtyas et al. (2017) defined intention to buy as the probability of consumer desire to purchase in the future. Consumers do not make a decision to buy, but sometimes they take possession of an intention to make transactions. According to Hosein (2012) classified purchase intention as one of the items of consumer cognitive attitude on how an individual intends to purchase a specific brand or product. Moreover, Tariq et al. (2013) defined purchase intention as a multi-step process that attends to personal customer experience in order to develop the product knowledge on a certain product.



Fig. 1. Conceptual Model

According to Godey et al. (2016) social media marketing became an important tool to build brand image. Marketing activities in social media have a significant effect on consumers' brand image (Bilgin, 2018). Further research also concludes brand image positively affected by social media marketing activities (Seo \& Park, 2018).

\section{H1: Social Media Marketing positively influences Brand Image.}

Consumers' marketing experience is importantly driven by social media and it is positively affecting brand trust (Tatar \& Erdoğmuş, 2016). There are few things that determine the trust variable, trust and commitment are the most crucial and imperative variables to manage long-term relationships between businesses and consumers (Takaya, 2019). Mostly, a longterm solution to maintain this relationship leads by interactive communications related with product customization, larger collections of product variety, knowledge regarding the brand history, and transparent price of product (Mosavi \& Kenarehfard, 2013). Furthermore, Elaydi (2018) has found interaction and communication between users and brands can occur through that brand's social media platforms. Therefore, it may be reasonable to assume that marketing through social media would positively impact brand trust.

\section{H2: Social Media Marketing positively influences Brand Trust.}

Aydin et al. (2014) revealed that brand trust has positive effects on purchasing intention for national brands. There is an effect between brand trust and purchase intention, which means if the brand trust has increased, then the value of purchase intention will increase (Takaya, 2019). Punyatoya (2016) assumed that trust in a brand contributes to higher purchase intention. According to, Limbu et al. (2012) effective and proactive marketing communication can build a positive relationship between trust and purchase intention.

H3: Brand Trust positively influences Purchase Intention. 
As described in section brand image and purchase intention, brand image could affect the consumer's purchase intention. A product that has a high brand image often perceived has a better quality rather than product that came from companies with lower brand image (Sallam, 2016). Thus, as it has correlation to product quality on consumers' perspective, brand image gives the biggest positive effect on consumer buying intention (Erida \& Rangkuti, 2017). Omar et al. (2012) revealed that brand image has a positive impact on consumers' purchase intention. According to Razy \& Lajevardi (2015) they indicate that brand image does give influence to consumers' purchase intention, the stronger products' brand image, the more purchase intention there is.

\section{H4: Brand Image positively influences Purchase Intention.}

\section{Methodology}

Research uses a quantitative approach. The selected population includes Indonesian men who actively use social media such as Instagram, YouTube, Facebook and Twitter. The criteria of respondents were a millennial man with age of participants ranged from 19 to 39 years and have been watched skincare ads on social media. The respondents of the research were 203 respondents. Primary data obtained through the distribution in the form through online questionnaire, shared in the social media applications such as Instagram, WhatsApp, and Line. The questionnaires consisted of close-ended questions, using non-probability sampling techniques with convenience sampling method. The convenience sampling method is suitable in this study since the chosen subject is quite close and affordable for researchers. Besides, convenience sampling method which is one type of non-probability sampling technique has easy accessibility and time flexibility to participate in research. Data collection is accomplished by distributing survey questionnaires to respondents through online surveys. The research aims to analyse the impact of social media marketing on brand image and brand trust toward the purchase intention of Indonesian male's skincare. To ensure content validity, most of the items are selected by adapted from previous studies. Six dimensions for the Social Media Marketing construct are also adapted from Bilgin (2018) and Godey et al. (2016). The measurement of brand image is composed of six items using Chen (2010) and Woo (2019). A measurement of brand trust is based on six items adapted from the study of Kabadayi and Alan (2012) and Mosavi and Kenarehfard (2013). Finally, Purchase Intention is measured by five items adapted from Mhlophe (2016) and Lee (2018). Required data for the study are collected through questionnaire, the type of measurement using 5-point Likert scale with anchors ranging from "strongly disagree" to "strongly agree". The wording of items questionnaire is modified based on the research context. The research implemented the dependent variable (Y), which is the purchase intention, the independent variable includes Social Media Marketing (X1), the intervening variables which are the brand image (Z1) and Brand Trust (Z2). The data process in this research have implemented the use of software named SmartPLS.

\section{Analysis and result}

The data collected through the online survey were analysed with Smart-PLS program to validate the measurements and test the hypotheses in this study. For the final survey, 203 questionnaires were collected and retained for analysis. PLS-SEM methodologies considered to be applied when the research is exploratory or an extension of existing structural theory and if the structural models are more complex (Hair et al., 2011). The attributes of respondents will be explained in this section, including gender, age, domicile, the skincare user, the type of skincare that they used, how many times that they changed their skincare, what type of their skincare and which platform they prefer to see skincare advertisement for.

Table 1

Sample demographics

\begin{tabular}{|c|c|c|c|c|c|}
\hline \multicolumn{2}{|l|}{ Demographic } & \multirow{2}{*}{$\begin{array}{c}\text { Percentage (\%) } \\
100 \%\end{array}$} & \multicolumn{2}{|l|}{ Demographic } & \multirow{2}{*}{$\frac{\text { Percentage (\%) }}{66 \%}$} \\
\hline Gender & Male & & \multirow{3}{*}{$\begin{array}{l}\text { Skincare for man } \\
\text { user }\end{array}$} & Yes & \\
\hline \multirow{3}{*}{ Age } & $19-25$ & $86.50 \%$ & & No & $16 \%$ \\
\hline & $26-32$ & $11.30 \%$ & & Probably & $17.90 \%$ \\
\hline & $33-39$ & $2.30 \%$ & \multirow{2}{*}{$\begin{array}{l}\text { Have switch to other } \\
\text { skincare brand }\end{array}$} & Yes & $61.50 \%$ \\
\hline \multirow{6}{*}{ Region } & Java & $77.50 \%$ & & No & $38.50 \%$ \\
\hline & Sumatera & $4.50 \%$ & \multirow{3}{*}{$\begin{array}{l}\text { Frequent of switch- } \\
\text { ing brand }\end{array}$} & Once & $23.10 \%$ \\
\hline & Kalimantan & $2.30 \%$ & & Two times & $16.50 \%$ \\
\hline & Bali & $8.60 \%$ & & More than three times & $47.90 \%$ \\
\hline & Papua & $0.90 \%$ & \multirow{5}{*}{$\begin{array}{l}\text { Platform of } \\
\text { information }\end{array}$} & Facebook \& LinkedIn & $14.60 \%$ \\
\hline & Others & $6.20 \%$ & & Twitter & $11.90 \%$ \\
\hline \multirow{3}{*}{ Skincare User } & Yes & $70 \%$ & & You-Tube \& Instagram & $81.30 \%$ \\
\hline & No & $16.20 \%$ & & Forum \& blog & $16.40 \%$ \\
\hline & No, but willing & $13.50 \%$ & & & \\
\hline
\end{tabular}

The reliability of the measurements was evaluated using the composite reliability scores and the Average Variance Extracted (AVE). As Table 2 shows, the composite reliability scores of all of the constructs are considered qualified for the recommended criterion of reliability as they surpass the recommended cut off of 0.70 . Furthermore, reliability was supported by the 
square root of the average variance extracted (AVE) result that suggested being above 0.50 that the principal constructs capture much higher construct-related variance than error variance. Data validation was supported by item's loading results shown on its underlying construct is above the recommended 0.70 level as recommended from Xue et al. (2011). Moreover, discriminant validity has been examined by the comparison of the shared variances among the construct with the AVE of individual constructs. According to Chang et al. (2009), the square root of AVE for each construct would verify the discriminant validity results when it is generally higher than correlation with any other constructs within the framework model (Table 3 ). The validity of social media marketing is supported by the path weights of its six first-order constructs, since social media marketing is a formative second-order construct of customization, advertisement, entertainment, interaction, trendiness, and word of mouth are $0.123,0.270,0.251,0.172,0.178$, and $0.188(\mathrm{p}<0.05)$. In addition, to determine multicollinearity, variance inflation factor (VIF) score for each first-order social media marketing construct of customization, advertisement, entertainment, interaction, trendiness, and word of mouth are 2.253, 3.639, 2.608, 2.256, 4.112, and 2.253, respectively. These results are below of a recommended maximum VIF value of 5 (Rogerson, 2001).

Table 2

Convergent Validity and Composite Reliability

\begin{tabular}{|c|c|c|c|c|}
\hline Construct & Item & Loadings & Composite Reliability & $\begin{array}{l}\text { Average Variance } \\
\text { Extracted (AVE) }\end{array}$ \\
\hline \multirow[t]{3}{*}{ 1. Advertisement } & ADV1 & 0.848 & 0.857 & 0.667 \\
\hline & ADV2 & 0.77 & & \\
\hline & ADV3 & 0.83 & & \\
\hline \multirow[t]{4}{*}{ 2. Brand Image } & BI1 & 0.717 & 0.878 & 0.643 \\
\hline & $\mathrm{BI} 2$ & 0.82 & & \\
\hline & $\mathrm{BI} 3$ & 0.858 & & \\
\hline & BI4 & 0.805 & & \\
\hline \multirow[t]{5}{*}{ 3. $\quad$ Brand Trust } & BT1 & 0.847 & 0.917 & 0.688 \\
\hline & BT2 & 0.845 & & \\
\hline & BT3 & 0.871 & & \\
\hline & BT4 & 0.792 & & \\
\hline & BT5 & 0.788 & & \\
\hline \multirow[t]{2}{*}{ 4. Customization } & CUS1 & 0.86 & 0.804 & 0.673 \\
\hline & CUS2 & 0.779 & & \\
\hline \multirow[t]{3}{*}{ 5. $\quad$ Entertainment } & ENT1 & 0.857 & 0.882 & 0.714 \\
\hline & ENT2 & 0.832 & & \\
\hline & ENT3 & 0.846 & & \\
\hline \multirow[t]{2}{*}{ 6. Interaction } & INT1 & 0.875 & 0.835 & 0.717 \\
\hline & INT2 & 0.818 & & \\
\hline \multirow[t]{3}{*}{ 7. $\quad$ Purchase Intention } & PI1 & 0.824 & 0.804 & 0.579 \\
\hline & PI2 & 0.731 & & \\
\hline & PI3 & 0.724 & & \\
\hline \multirow[t]{2}{*}{ 8. $\quad$ Trendiness } & TR1 & 0.818 & 0.817 & 0.691 \\
\hline & TR2 & 0.844 & & \\
\hline \multirow[t]{2}{*}{ 9. Word of Mouth } & WOM1 & 0.881 & 0.868 & 0.766 \\
\hline & WOM2 & 0.87 & & \\
\hline
\end{tabular}

Table 3

Discriminant Validity

\begin{tabular}{|c|c|c|c|c|c|c|c|c|c|}
\hline Variables & 1 & 2 & 3 & 4 & 5 & 6 & 7 & 8 & 9 \\
\hline 1. Advertisement & 0.816 & & & & & & & & \\
\hline 2. Brand Image & 0.733 & 0.802 & & & & & & & \\
\hline 3. Brand Trust & 0.691 & 0.800 & 0.829 & & & & & & \\
\hline 4. Customization & 0.667 & 0.462 & 0.481 & 0.820 & & & & & \\
\hline 5. Entertainment & 0.679 & 0.547 & 0.700 & 0.641 & 0.845 & & & & \\
\hline 6. Interaction & 0.646 & 0.566 & 0.704 & 0.569 & 0.627 & 0.847 & & & \\
\hline 7. Purchase Intention & 0.685 & 0.733 & 0.679 & 0.432 & 0.499 & 0.518 & 0.761 & & \\
\hline 8. Trendiness & 0.820 & 0.644 & 0.715 & 0.652 & 0.736 & 0.657 & 0.613 & 0.831 & \\
\hline 9. Word of Mouth & 0.640 & 0.658 & 0.722 & 0.390 & 0.581 & 0.631 & 0.517 & 0.670 & 0.875 \\
\hline
\end{tabular}

Table 4

Results of Model Test

\begin{tabular}{|c|c|c|c|c|}
\hline Hypotheses & Path Coefficients & T Statistics & $\mathrm{P}$ value & Results \\
\hline H1. Social Media Marketing positively influences Brand Image & 0.732 & 16.279 & 0.000 & Supported \\
\hline H2. Social Media Marketing positively influences Brand Trust & 0.809 & 30.799 & 0.000 & Supported \\
\hline H3. Brand Trust positively influences Purchase Intention & 0.255 & 2.003 & 0.045 & Supported \\
\hline H4. Brand Image positively influences Purchase Intention & 0.529 & 4.300 & 0.000 & Supported \\
\hline
\end{tabular}






Notes:

$=$ Second-Order Construct

$* * p<0.05$

Fig. 2. Conceptual Model Result

The proposed structural equation model result is shown in Fig. 2. Brand image has been found to significantly affect purchase intention (path coefficient $=.259, \mathrm{p}=.05$ ), and brand trust result (path coefficient $=.255, \mathrm{p}=.05$ ) which means brand image and brand trust describe 56.1 percent of the purchase intention. Thus, these two results supported H3 and H4. Furthermore, Social media marketing has been found to significantly affect brand image (path coefficient $=.732 ; \mathrm{p}=.05$ ), and supported $\mathrm{H} 1$ with 53.6 percent social media marketing explains the brand image. Besides, $\mathrm{H} 2$ is supported by the social media marketing result towards brand trust (path coefficient $=.809, \mathrm{p}=.05$ ) with 65.4 percent social media marketing explained the brand trust. In conclusion, the results have indicated that the study was successful. All of the hypotheses were supported. Most male consumers are easily influenced by advertisements on social media and have an impact on their brand image and brand trust, thus, it can influence their purchase intention to male's skincare products. Overall, the study has demonstrated that social media marketing has a positive impact on brand trust and brand image. Hence, purchase intention is also affected by brand trust and brand image. The findings of this study have provided a few implications for the skincare industries and researchers. Furthermore, this research will help out the skincare industries gain knowledge on consumers' purchase intention supported by this result that is able to enhance insight and provide deeper knowledge from the existing studies. Consumers' purchase intention became a consumers' process to gain the product knowledge. The results have shown, respondents' purchase intention on male's skincare products came out when they desired to enhance their personal appearance and the purchase intention linked to their perspective of certain skincare products that they have seen on social media ads as well. Hence, these findings might help the skincare industries begin concerning on male's skincare product that has specific function to enhance consumer's appearance such as oil control, acne free or anti-dull skin which became common skin problems in Indonesia since they would prefer to use skincare for men and it is still spares. Through this research, there are several ways in order to increase the purchase intention on male's skincare products by applying approaches toward several variables such as brand image, brand trust, and social media marketing. To increase purchase intention on male's skincare products, the company can improve their brand image and brand trust through appropriately social media platforms for targeted customers in terms of marketing strategies. According to Erida \& Rangkuti (2017), consumer purchase intentions are strongly influenced by brand image, and so increased on brand trust will increase the value of purchase intention (Takaya, 2019). This fact can be supported by the result when brand image and brand trust positively affect the purchase intention, with Dehesti et al. (2016) believed that if the companies are able to improve their brand image, they would win consumers' trust to the brand. That might occur since brand image found to be suitable predictor for brand trust and may influence consumers' purchase intention. Hence, to improve the brand image Wijaya (2013) revealed brand alliances became a popular strategy associated with brand partners. Since this study targeted on the millennial generation, entertaining, unique and attractive advertisements through social media have to be applied to approach these generations. The results have shown skincare brand that consumers seen on social media ads are trustworthy about their skin concern.

On the other side, companies have to be more concerned to share their marketing campaigns through You-Tube and Instagram since these platforms became millennial preference, with an attractive content and collaborating with beauty influencers, or even create an official account on social media to increase purchase intention. Social media marketing seems to become marketing tool for companies' strategy. Social media presence would be able to make the company take chances by investing into their marketing and develop more targeted campaigns, interact with their consumers, driven direct sales by utilizing the social media as a medium, creating research and development through consumer's behaviours and how they appreciate a brand in their social media (Vinerean, 2017). The targeted customers would take distinct social media platforms to reach them, depending on their preference which can be affected by gender, generations and behaviour. According to Voorveld et al. (2018), social media platforms are distinguished into four categories which in this study creative outlet platforms.

\section{Conclusion}

The results are in line with the millennial generation characteristics that advertisement and entertainment matters to them when certain skincare brands apply their marketing through social media. Besides, skincare customers are found to tend to 
switch their skincare brand more than twice. On top of that, consumer's considered skincare brand advertisements that they have seen on social media is more trustworthy about its function since this study has proven that consumer's purchase intentions towards the skincare product were also to enhance their external appearance, even for man. Therefore, these findings might help the skincare industries begin concerning on male's skincare product that has specific function to enhance consumer's appearance such as oil control, acne free or anti-dull skin which become common skin problems in Indonesia since they would prefer to use skincare for men and it is still spares. This strategy would impact the targeted consumers which tend to always look for another brand by its variety of product and differentiation.

\section{References}

Aydın, G., Ar, A. A., \& Taşkın, Ç. (2014). The role of brand trust on parents' purchase intentions of baby-care products. Universitesi Dergisi, 2(15), 165-180.

Bilgin, Y. (2018). The effect of social media marketing activities on brand awareness, brand image and brand loyalty. Business \& Management Studies: An International Journal, 6(1), 128-148.

CAKMAK, I. (2016). The role of brand awareness on brand image, perceived quality and effect on risk in create brand trust. New Trends and Issues Proceedings on Humanities and Social Sciences, 2(2), 177-186.

Chang, H. H., Wang, Y. H., \& Yang, W. Y. (2009). The impact of e-service quality, customer satisfaction and loyalty on emarketing: Moderating effect of perceived value. Total Quality Management and Business Excellence, $20(4), 423-443$.

Chaudhuri, A., \& Holbrook, M. B. (2001). The chain of effects from brand trust and brand affect to brand performance: the role of brand loyalty. Journal of Marketing, 65(2), 81-93.

Chinomona, R., \& Maziriri, E. T. (2017). The influence of brand awareness, brand association and product quality on brand loyalty and repurchase intention: a case of male consumers for cosmetic brands in South Africa. Journal of Business and Retail Management Research, 12(1).

Chen, Y. S. (2010). The drivers of green brand equity: Green brand image, green satisfaction, and green trust. Journal of Business ethics, 93(2), 307-319.

Deheshti, M., Adabi Firouzjah, J., \& Alimohammadi, H. (2016). The relationship between brand image and brand trust in sporting goods Consumers. Annals of Applied Sport Science, 4(3), 27-34.

Elaydi, H. O. (2018). The effect of social media marketing on brand awareness through Facebook: An individual-based perspective of mobile services Sector in Egypt.

Eng, T. C., Ahmad, F. S., \& Onn, C. Y. (2018). Conceptual study on Malaysian male consumption behaviour towards skin care products. In Postgraduate Colloquium 2015 (p. 182).

Erida, E., \& Rangkuti, A. S. (2017). The effect of brand image, product knowledge and product quality on purchase intention of notebook with discount price as moderating variable. Journal of Business Studies and Management Review, 1(1), 2632.

Godey, B., Manthiou, A., Pederzoli, D., Rokka, J., Aiello, G., Donvito, R., \& Singh, R. (2016). Social media marketing efforts of luxury brands: Influence on brand equity and consumer behavior. Journal of Business Research, 69(12), 5833-5841.

Foster, B. (2016). Impact of brand image on purchasing decision on mineral water product "Amidis"(Case study on bintang trading company). American Research Journal of Humanities and Social Sciences, 2, 1-11.

Global Business Guide. (2014). Retrieved October 2019, from http://www.gbgindonesia.com/en/manufacturing/article/2014/indonesia s cosmetics market.php

Hair, J. F., Ringle, C. M., \& Sarstedt, M. (2011). PLS-SEM: Indeed a silver bullet. Journal of Marketing Theory and Practice, 19(2), 139-151.

Herdiyanti, N., \& Titus, A. (2013). Research on market trends and consumer behavior in male grooming products (Especially face cleanser category) in Indonesia. Indonesian Journal of Business Administration, 2(6), 663-671.

Hermanda, A., Sumarwan, U., \& Tinaprilla, D. N. (2019). The effect of social media influencer on brand image, self-concept, and purchase intention. Journal of Consumer Sciences E, 04(02), 76-89.

Hosein, N. Z. (2012). Measuring the purchase intention of visitors to the auto show. Journal of Management \& Marketing Research, 9, 1-17.

Junaid, A. Bin, \& Nasreen, R. (2012). Determination of Consumer Behavior amongst Millennials in Dermaceuticals (Skin Care Products). International Journal of Marketing Studies, 4(3), 88-99.

Kabadayi, E. T. \& Alan, A. K. (2012). Brand trust and brand affect: their strategic importance on brand loyalty. Journal of Global Strategic Management, 11,80-88.

Karman, A. M. (2017). The impact of social media marketing on brand loyalty. Annals of Applied Sport Science, 5(1), 73-80.

Kemp, S. (2019, January). Retrieved September 2019, fromhttps://datareportal.com/reports/digital-2019-indonesia

Khan, I., Dongping, H., Abdullah, M., Ahmad, Z., Ahmad Ghauri, T., \& Ghazanfar, S. (2017). Men's attitude and motivation toward consumption of grooming products: A comparison of Chinese and Pakistani male consumers. Cogent Business \& Management, 4(1), 1309783.

Kim, E. J., Kim, S. H., \& Lee, Y. K. (2019). The effects of brand hearsay on brand trust and brand attitudes. Journal of Hospitality Marketing \& Management, 28(7), 765-784.

Lee, J. E., Goh, M. L., \& Noor, M. N. B. M. (2019). Understanding purchase intention of university students towards skin care products. PSU Research Review. 
Lee, J., \& Lee, Y. (2018). Effects of multi-brand company's CSR activities on purchase intention through a mediating role of corporate image and brand image. Journal of Fashion Marketing and Management: An International Journal.

Limbu, Y. B., Wolf, M., \& Lunsford, D. (2012). Perceived ethics of online retailers and consumer behavioral intentions. Journal of Research in Interactive Marketing, 6(2), 133-154.

MDG Advertising. (2014, October 30). What's Social Medias Actual Advertising Contribution? (MDG Advertising) Retrieved February 2019, from MDG Blog: http://www.mdgadvertising.com/blog/whatssocial-medias-actualadvertisingcontribution/

Mhlophe, B. (2016). Consumer purchase intentions towards organic food: insights from South Africa. Business \& Social Sciences Journal, 1(1), 1-32.

Mosavi, S. A., \& Kenarehfard, M. (2013). The impact of value creation practices on brand trust and loyalty in a Samsung galaxy online brand community in Iran. International Journal of Mobile Marketing, 8(2), 75-84.

Omar, K. M., Kamariah Nik Mat, N., Ahmed Imhemed, G., \& Mahdi Ahamed Ali, F. (2012). The direct effects of halal product actual purchase antecedents among the international Muslim consumers. American Journal of Economics, 2(4), 87-92.

Punyatoya, P. (2014). Linking environmental awareness and perceived brand Ecofriendliness to brand trust and purchase intention. Global Business Review, 15(2), 279-289.

Rahmaningtyas, A., Slamet, H. \& Ani, S. (2017). Factors affecting online purchasing of local food. Agro Ekonomi, 28(2), 189204.

Razy, F. F., \& Lajevardi, M. (2015). Investigating relationship between brand image, price discount and purchase intention. Journal of Marketing and Consumer Research, 17, 49-56.

Rogerson, P. A. (2001). Statistical methods for geography. London: Sage.

Sallam, M. A. (2016). The impact of brand image and corporate branding on consumer's choice: The role of brand equity. International Journal of Marketing Studies, 8(1),98.

Seo, E. J., \& Park, J. W. (2018). A study on the effects of social media marketing activities on brand equity and customer response in the airline industry. Journal of Air Transport Management, 66(September 2017), 36-41.

Takaya, R. (2019). The effect of celebrity endorsement on brand image and trust brand and it's impact to purchase intention Case study: Oppo Smartphone. Business and Entrepreneurial Review, 17(2), 183.

Tariq, M. I., Nawaz, M. R., Nawaz, M. M., \& Butt, H. A. (2013). Customer perceptions about branding and purchase intention: A study of FMCG in an emerging market. Journal of Basic and Applied Scientific Research, 3(2), 340-347.

Tatar, Ş. B., \& Eren-Erdoğmuş, İ. (2016). The effect of social media marketing on brand trust and brand loyalty for hotels. Information Technology and Tourism, 16(3), 249-263.

Vinerean, S. (2017). Importance of Strategic Social Media Marketing. Expert Journal of Marketing, 5(1), $28-35$.

Voorveld, H. A. M., van Noort, G., Muntinga, D. G., \& Bronner, F. (2018). Engagement with Social Media and Social Media Advertising: The Differentiating Role of Platform Type. Journal of Advertising, 47(1), 38-54.

Wijaya, B. (2013). Dimensions of Brand Image: A Conceptual Review from the Perspective of Brand Communication. European Journal of Business and Management, 5.

Wijaya, B. S., \& Wijaya, B. S. (2013). A strategic study on foreign fund utilization in Chinese insurance industry. European Journal of Business and Management, 5(31), 55-65.

Woo, H. (2019). The expanded halo model of brand image, country image and product image in the context of three Asian countries. Asia Pacific Journal of Marketing and Logistics.

Xue, Y., Bradley, J., \& Liang, H. (2011). Team climate, empowering leadership, and knowledge sharing. Journal of Knowledge Management, 15(2), 299-312.

Yee, E. (2018, December). CNBC. Retrieved from https://www.cnbc.com/2018/12/07/beautycompany-rejects-traditionalskin-regimens-claims-ai-is-answer.html



(C) 2020 by the authors; licensee Growing Science, Canada. This is an open access article distributed under the terms and conditions of the Creative Commons Attribution (CC-BY) license (http://creativecommons.org/licenses/by/4.0/). 